\title{
THE EFFECT OF FINANCING TO DEPOSIT RATIO (FDR) AND THE MONEY SUPPLY ON PROFITABILITAS IN SHARIA BUSINESS UNIT FOR THE 2016-2020 PERIOD
}

\author{
Mutiah Khaira Sihotang \\ Universitas Muhammadiyah Sumatera Utara \\ mutiahkhaira@umsu.ac.id
}

\begin{abstract}
This study aims to determine the effect of FDR and the money supply on profitability as proxied by Return On Assets (ROA), a study on Sharia Business Units for the 2016-2020 period. The sample selection in this study used purposive sampling method. The population in this study is the financial statements of Sharia Business Units in Indonesia and the sample in this study is the monthly financial statements of Sharia Business Units in Indonesia for 2016-2020. The data in this study will be processed using SPSS software with multiple regression. The results of this study state that partially the independent variables in this study are Financing to Deposit Ratio (FDR) and the money supply has a significant effect on Return On Assets (ROA) of Islamic Business Units in Indonesia with a significance level of 0.000. Then, simultaneously Financing to Deposit Ratio (FDR) and the money supply have a significant effect on the Return On Assets (ROA) of Sharia Business Units in Indonesia with a significance level of 0.000 and an fhitung value of 50,742 .
\end{abstract}

Keywords: FDR, money supply, ROA

\section{INTRODUCTION}

Islamic banking has developed in line with government regulations on Islamic banking. This has been clearly seen since the issuance of Law no. 20 of 2008 concerning Islamic banking on July 16, 2008. Asset growth has been impressively increasing by more than $65 \%$ per year. According to OJK data as of June 2019, there are 14 Sharia Commercial Banks (BUS), 20 commercial banks that have Sharia Business Units (UUS) and 164 Sharia People's Financing Banks (BPRS). As time goes by, the number of Sharia Commercial Banks will likely increase due to the conversion of Sharia Business Units to Sharia Commercial Banks. Law No. 21 of 2008 concerning Sharia Banking Article 28 paragraph (1) explains that there are several criteria for the transition of a Sharia Business Unit (UUS) to a Sharia Commercial Bank (BUS), among others, it reads "In the event that a Conventional Commercial Bank has a UUS whose asset value has reached at least $50 \%$ (fifty percent) of the total value of the parent bank's assets or 15 (fifteen) years since the enactment of this Law, the said Conventional Commercial Bank is obligated to separate the UUS into a Sharia Commercial Bank". 
Islamic banking as an institution that contributes to the development of the Islamic economy in Indonesia requires good performance supervision by the Islamic banking regulator. One aspect to assess the financial performance of a bank can be seen through the level of profitability. Profitability can be measured using several ratios, one of which is ROA (Return On Total Assets). This ratio measures the company's ability to utilize its assets to earn a profit and measures the rate of return on investment that has been made by the company using all of its funds (assets). Then another ratio that can be used to assess the performance of Islamic banks is the Financial to Deposit Ratio (FDR). This ratio is a ratio used to measure the liquidity of a bank in paying back withdrawals made by depositors by relying on the financing provided as a source of liquidity. If the liquidity of Islamic banks is good, it will affect the level of profitability which in this study is proxied by Return On Assets (ROA). FDR is one of the internal factors that can affect the profitability of sharia business units.

\section{Table 1. ROA, FDR da JUB Unit Usaha Syariah Periode 2019-2020}

\begin{tabular}{|c|c|c|c|}
\hline Tahun & FDR & ROA & JUB \\
\hline 2019 & 77.92 & 1.51 & $1,376,135.53$ \\
\hline & 77.52 & 1.32 & $1,386,329.31$ \\
\hline & 78.38 & 1.46 & $1,428,606.53$ \\
\hline & 79.57 & 1.52 & $1,454,278.57$ \\
\hline & 82.01 & 1.56 & $1,508,039.89$ \\
\hline & 79.74 & 1.61 & $1,513,519.72$ \\
\hline & 79.9 & 1.62 & $1,487,801.78$ \\
\hline & 80.85 & 1.64 & $1,475,544.35$ \\
\hline & 81.56 & 1.66 & $1,508,817.97$ \\
\hline & 79.1 & 1.65 & $1,504,156.28$ \\
\hline & 80.06 & 1.67 & $1,553,134.22$ \\
\hline & 77.91 & 1.73 & $1,565,358.44$ \\
\hline 2020 & 77.8 & 1.88 & $1,484,402.62$ \\
\hline & 77.02 & 1.86 & $1,505,490.52$ \\
\hline & 78.83 & 1.88 & $1,648,681.33$ \\
\hline & 78.89 & 1.66 & $1,576,401.28$ \\
\hline & 80.6 & 1.44 & $1,653,610.64$ \\
\hline & 78.73 & 1.4 & $1,637,750.66$ \\
\hline & 81.03 & 1.38 & $1,683,193.63$ \\
\hline & 79.68 & 1.38 & $1,765,264.02$ \\
\hline & 77.08 & 1.38 & $1,780,721.41$ \\
\hline & 77.06 & 1.36 & $1,782,244.23$ \\
\hline & 77.81 & 1.36 & $1,799,087.27$ \\
\hline & 78.38 & 1.4 & $1,855,624.80$ \\
\hline & & & \\
\hline
\end{tabular}

In addition to internal factors, there are also external factors that can affect the profitability of sharia business units. One of them is the amount of money circulating in the community. In theory, the more money circulating in the community, the worse the effect on Islamic banks. This is due to the lack of public interest in making savings transactions at Islamic 
banks. So, between FDR and the money supply has a significant influence on the level of profitability of Islamic banks which in this study is proxied by Return On Assets (ROA).

The following is the value of ROA, FDR and the money supply (JUB) of sharia business units for the 2019-2020 period. Table 1 explains that the ROA and NPF ratios as well as the money supply from 2019 to 2020 fluctuate every month. When the FDR ratio increases, the profitability as measured by ROA tends to increase. Vice versa, if the FDR value decreases, the ROA value also decreases. The increasing money supply will affect the decrease in the value of profitability. And vice versa if the money supply is reduced it will increase the value of profitability. The same can be seen in table 1 above. However, this does not always happen, there are times when the increase in the money supply makes the value of profitability increase. This happens due to the economic conditions of a country.

\section{METHOD}

This study uses a quantitative approach, namely data measured by a numeric scale, based on time series data related to the ratio of Financing to Deposit Ratio (FDR), Return On Assets (ROA) and the amount of money circulating in sharia business units obtained from the OJK website.

The population of this study is the data contained in the financial statements in the form of balance sheets and income statements. In this case the monthly financial statements of Sharia Business Units in Indonesia. The sample of this research is the financial statements, namely the monthly balance sheet and profit and loss report for Sharia Business Units in Indonesia for the 2016-2020 period. The sample selection method used is purposive sampling, which is a sampling method based on certain objectives and considerations, in this case the sample taken is the financial statements of Sharia Business Units in Indonesia for the 2016-2020 period. This is because the data is easy to obtain and is the latest data so that it is still relevant today. The data used is secondary data, namely the internal data of Sharia Business Units in Indonesia in the form of monthly financial reports published for the 2016-2020 period. The data collection instrument in this research is the documentation study. The data collection technique in this study was carried out by studying documents sourced from secondary data obtained from Bank Indonesia published reports in the form of monthly financial reports of Sharia Business Units in Indonesia 2016-2020.

The statistical test used in this study uses a multiple linear regression model that uses two independent variables. Regression analysis is used to measure changes in the dependent variable based on changes in the independent variables. Testing the effect of two or more independent 
variables on the dependent variable is used using the ordinary least square method, which is a method to determine the regression equation based on the difference between the squares of the actual (actual) value with a minimum estimated or predicted y value or can be written down $(y-)$ is minimal. The equation model can be written as follows:

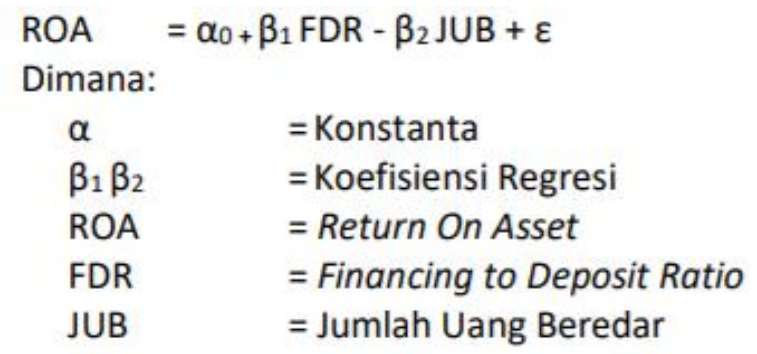

The data normality test is intended to test the alignment of data from all respondents on research variables that are normally distributed or not. and required in multiple regression analysis. Multicollinearity means that one independent variable and another independent variable in the regression model are linearly correlated. Usually, the correlation is near perfect or perfect. The heteroscedasticity test aims to test whether in the linear regression model there is an inequality of variance from the residuals of one observation to another observation. A good regression model is one with homoscedasticity or no heteroscedasticity.

The $\mathrm{R}^{2}$ test is essentially to measure the ability of the model to explain the dependent variable or how much the independent variable (financing deposit rartio and supply demand) has on the dependent variable (return on assets). $\mathrm{T}$ test was conducted to determine the effect of each independent variable (current ratio, debt to equity ratio, working capital turnover and total asset turnover) individually (partial) on the dependent variable (return on assets). The F test was conducted to determine the effect of the independent variables (financing to deposit ratio and supply demand) on the dependent variable (return on assets) together.

\section{RESULT AND DISCUSSION}

\section{Descriptive Analysis}

Descriptive statistics are statistics related to data collection. The data in this study were obtained from the monthly financial statements of Sharia Business Units in Indonesia for the period 2016 to 2020, namely the ratio of FDR, ROA and the amount of money in circulation. In this study, descriptive analysis was used to see the effect between each variable FDR and the amount of money in circulation on the ROA of Islamic Business Units in Indonesia. The sample taken to determine the effect between the independent variable and the dependent variable is 60 
months, the data is obtained from the financial statements. The financial ratio data was tested by descriptive analysis by first transforming the data on the ROA, FDR and money supply variables. The descriptive output results can be seen in the table below:

Table 2. table Output Descriptive Statistics

Descriptive Statistics

\begin{tabular}{|l|r|r|r|}
\hline & \multicolumn{1}{|c|}{ Mean } & $\begin{array}{c}\text { Std. } \\
\text { Deviation }\end{array}$ & N \\
\hline Y & 1.4120 & .64175 & 60 \\
X1 & 86.9400 & 10.11255 & 60 \\
X2 & 1392626.942 & 200965.0515 & 60 \\
& 5 & 6 & 6 \\
\hline
\end{tabular}

The mean value for the Return On Asset (Y) variable in the table above is 1.4120 with a deviation value of 0.64175. then for the variable Financing to Deposit Ratio (X1) the mean value is 86.9400 and 10.11255 for the deviation value. The money supply (X2) has a mean value of 1392626.9425 with a deviation value of 200965.05156 .

\section{Diagnostic Test}

Data normality test is a common thing to do before a statistical method. The purpose of the normality test is to find out whether the distribution of a data follows or approaches a normal distribution, namely the distribution of data that has a pattern like a normal distribution (the data distribution does not deviate to the left or right). Good variable data is data that has a curve shape with a slope of the right and left sides, not skewed to the left or right, but to the center with a bell-like shape with close to 0 .

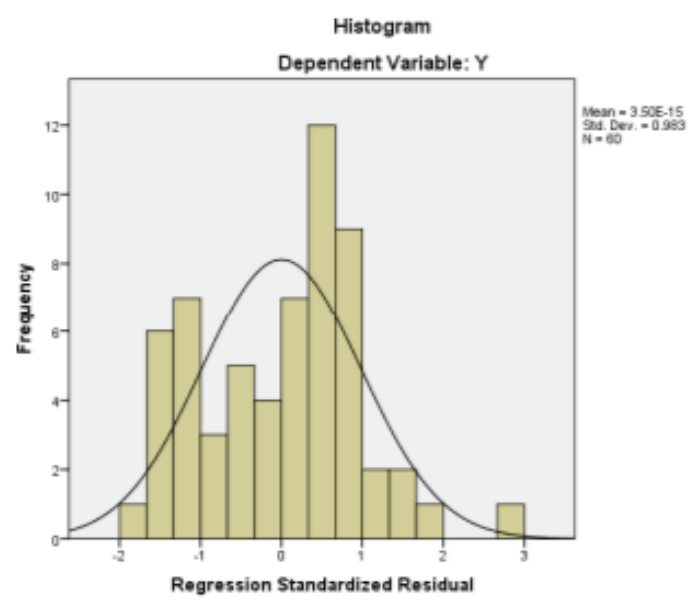

Gambar 1. Histogram 


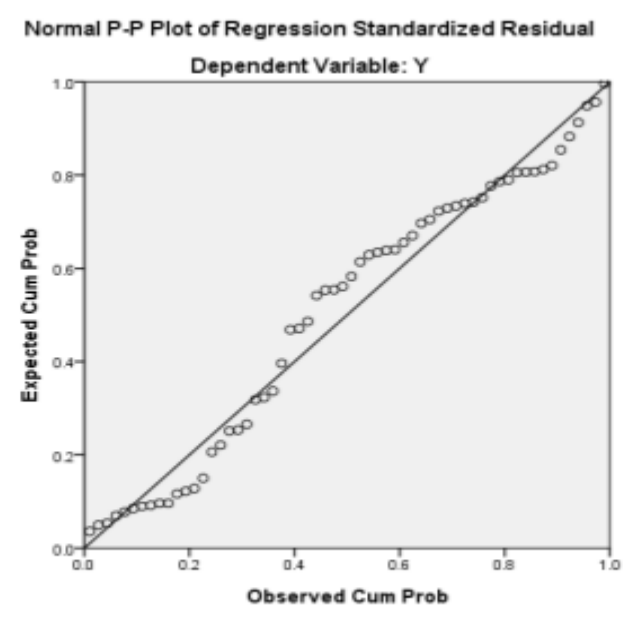

Gambar 2. Normal P-Plot

By looking at the histogram graph display and the normal p-plot graph, it can be concluded that the histogram graph provides a distribution pattern that is close to normal. In the Histogram graph, it can be seen that the spread of data resembles an inverted bell even though there are some data that are outside the bell line. Histogram resembling a bell shows the data is normally distributed. Meanwhile, on the normal p-plot graph, it can be seen that the dots spread around the diagonal line and follow the direction of the diagonal line. These two graphs show that the regression model is feasible because it fulfills the assumption of data normality.

Multicollinearity means that the independent variables contained in the regression model have a perfect or near perfect linear relationship (the correlation coefficient is high or even 1. A good regression model should not have a perfect or near perfect correlation between the independent variables. The consequence of multicollinearity is the variable correlation coefficient indefinite and the error becomes very large or infinity. One way to see if the regression model is affected by multicollinearity can be seen from the tolerance value which is smaller than 0.1 and the inflation factor (VIF) which is greater than 10. If this happens, it can be stated that the regression model is affected by multicollinearity disorders.

Tabel 3. Colinearity Statistic

\begin{tabular}{|c|c|c|c|}
\hline \multirow{2}{*}{\multicolumn{2}{|c|}{ Model }} & \multicolumn{2}{|c|}{ Collinearity Statistics } \\
\hline & & Tolerance & VIF \\
\hline \multirow[t]{3}{*}{1} & (Constant) & & \\
\hline & $\mathrm{X} 1$ & .893 & 1.120 \\
\hline & $\mathrm{X} 2$ & .893 & 1.120 \\
\hline
\end{tabular}

a. Dependent Variable: $Y$ 
From the output above, it can be seen that the tolerance value of the four variables is greater than 0.10 and the VIF is less than 10. It can be concluded that there is no multicollinearity between independent variables.

Heteroscedasticity test is used to test whether in a regression model there is a similarity or dissimilarity of variance between one observation and another observation. Heteroscedasticity testing uses a scatterplot graph. The following is a scatterplot graph display of the regression model in this study which is presented in Figure 3.

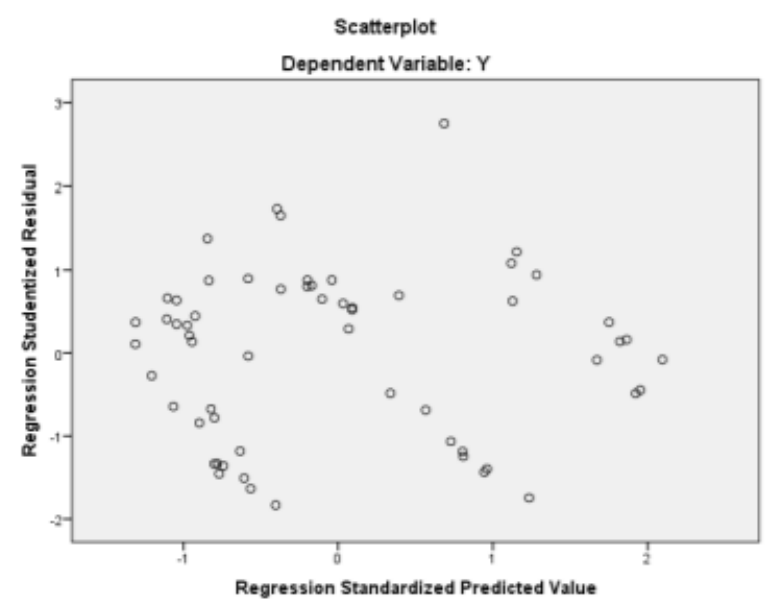

Gambar 3. Scatterplot

In a good regression model, usually does not experience heteroscedasticity. Through the scatterplot graph, it can be seen that a regression model has heteroscedasticity or not. If there is a certain pattern in the graph, it indicates that heteroscedasticity has occurred. From Figure 3 it can be seen that the points spread randomly and are spread both above and below the number 0 on the $\mathrm{Y}$ axis. It can be concluded that there is no heteroscedasticity in the regression model in this study.

Table 4. Model Summary

Model Summary ${ }^{b}$

\begin{tabular}{|l|c|r|r|r|r|}
\hline Model & $\mathrm{R}$ & $\mathrm{R}$ Square & $\begin{array}{c}\text { Adjusted R } \\
\text { Square }\end{array}$ & $\begin{array}{c}\text { Std. Error of } \\
\text { the Estimate }\end{array}$ & $\begin{array}{c}\text { Durbin- } \\
\text { Watson }\end{array}$ \\
\hline 1 & $.800^{\mathrm{a}}$ & .640 & .628 & .39156 & .611 \\
\hline
\end{tabular}

a. Predictors: (Constant), X2, X1

b. Dependent Variable: $Y$ 
The value of $\mathrm{R}$ indicates multiple correlation, namely the correlation between two or more independent variables on the dependent variable. The value of $R$ ranges from 0 to 1 . If the value of $\mathrm{R}$ is close to 1 , the relationship between the independent variable and the dependent variable will be closer, and vice versa. The $\mathrm{R}$ number is 0.800 , meaning that the correlation between the Financing to Deposit Ratio (FDR) variable and the money supply to Return On Assets $(\mathrm{ROA})$ is 0.7800 . This means that there is a very close relationship because the $\mathrm{R}$ value is close to 1 . R square (R2) shows the coefficient of determination. This figure will be converted into percent, meaning the percentage contribution of the influence of the independent variable to the dependent variable. The R2 value obtained is 0.640 or $64 \%$, meaning that the dependent variable on ROA can be explained by the independent variable, namely FDR and the amount of money in circulation. While the remaining 36\% is explained by other variables outside the research variables used.

The t-test can be seen from the coefficient table which aims to determine the magnitude of the influence of each independent variable individually on the dependent variable. The t-test is needed to test how much the independent variable, namely FDR and the money supply, has a partial effect on the dependent variable, namely ROA.

Tabel 5. Coefficients

Coefficients $^{\mathrm{a}}$

\begin{tabular}{|ll|r|r|r|r|r|}
\hline \multirow{2}{*}{ Model } & \multicolumn{2}{|c|}{$\begin{array}{c}\text { Unstandardized } \\
\text { Coefficients }\end{array}$} & \multicolumn{2}{c|}{$\begin{array}{c}\text { Standardized } \\
\text { Coefficients }\end{array}$} & & \\
\cline { 2 - 5 } & \multicolumn{1}{|c|}{ B } & Std. Error & \multicolumn{1}{c|}{ Beta } & \multicolumn{1}{c|}{ t } & \multicolumn{1}{c|}{ Sig. } \\
\hline 1 & (Constant) & -5.465 & .686 & & -7.967 & .000 \\
& X1 & .044 & .005 & .695 & 8.269 & .000 \\
& X2 & $2.185 \mathrm{E}-6$ & .000 & .684 & 8.140 & .000 \\
\hline
\end{tabular}

a. Dependent Variable: $Y$

Tabel 6. T-test

\begin{tabular}{|c|l|r|c|c|}
\hline No & \multicolumn{1}{|c|}{ Variabel } & $\mathbf{T}_{\text {hitung }}$ & & $\mathbf{T}_{\text {tabel }}$ \\
\hline 1 & FDR (X1) & 8.269 & $>$ & 2.001 \\
\hline 2 & JUB (X2) & 8.140 & $>$ & 2.001 \\
\hline
\end{tabular}

FDR $8,269>2,001$ then $\mathrm{H} 0$ is rejected, meaning that the financing to deposit ratio variable has a positive and partially significant effect on the return on assets variable with a significance level of 0.000 . JUB $8,140>2,001$ then $\mathrm{H} 0$ is rejected, meaning that the money supply variable has a positive and partially significant effect on the return on assets variable with a significance level of 0.000 . Simultaneous test with F-test is a statistical test that aims to 
determine the effect of the independent variables together on the dependent variable. For the Ftest, it can be seen from the Anova table below:

Table 7. ANOVA

\begin{tabular}{|c|c|c|c|c|c|c|}
\hline \multicolumn{7}{|c|}{ ANOVA $^{a}$} \\
\hline \multicolumn{2}{|c|}{ Model } & $\begin{array}{c}\text { Sum of } \\
\text { Squares }\end{array}$ & Df & $\begin{array}{l}\text { Mean } \\
\text { Square }\end{array}$ & $\mathrm{F}$ & Sig. \\
\hline \multirow[t]{3}{*}{1} & Regression & 15.560 & 2 & 7.780 & 50.742 & $.000^{b}$ \\
\hline & Residual & 8.739 & 57 & .153 & & \\
\hline & Total & 24.299 & 59 & & & \\
\hline
\end{tabular}

a. Dependent Variable: $Y$

b. Predictors: (Constant), X2, X1

From the ANOVA table above, it shows that the p-value is $0.000<0.05$ which means it is significant, then $\mathrm{Ha}$ is accepted and $\mathrm{H} 0$ is rejected, namely that the independent variables financing to deposit ratio and the money supply jointly affect the return on assets.

\section{CONCLUSION}

Based on the results of the research above, it can be concluded that the Financing to deposit ratio has a positive and significant effect on return on assets. The money supply has a positive and significant effect on return on assets and simultaneously, the variable FDR and the money supply have a significant effect on return on assets.

\section{REFERENCE}

Anggarini, Desy Tri. 2016. “Analisa Jumlah Uang Beredar di Indonesia Tahun 2005-2014”. Moneter. No. 2, Vol. 3.

Dermawan Wibisono.(2003). Riset Bisnis. Jakarta: Gramedia Pustaka Utama

Duwi Priyatno. (2009). 5 Jam Belajar Olah Data Dengan SPSS 17. Yogyakarta: ANDI

Eris, Irvany. 2017. "Pengaruh Tingkat Suku Bunga BI Rate, Jumlah Uang Beredar dan Neraca

Pembayaran terhadap Nilai Tukar Rupiah Tahun 2006- 2015”. Jurnal Ekonomi

Pembangunan. Fakulty Of Economi Riau Universty. No. 1, Vol. 4.Hery. 2016. Analisis Laporan Keuangan. Jakarta: Grasindo.

Hani, S. (2015). Analisis Laporan Keuangan. Medan: Umsu Press.

Isra Hayati. (2020). The Effect Of Current Ratio, Debt To Equity Ratio And Roa On Stock

Prices In Sharia Based Manufacturing Companies In Indonesia Stock Exchange. Proceeding International Seminar of Islamic Studies 
Ilhamsyah, F, L. (2017). Pengaruh Kebijakan Dividen, Keputusan Investasi, dan Profitabilitas Terhadap Nilai Perusahaan. Jurnal Ilmu dan Riset Manajemen, 6(2).

Kasmir. (2010). Analisis Laporan Keuangan. Jakarta: PT. Raja Grafindo Persada.

Linzzy Pratama Putri. (2015). Pengaruh Inflasi dan Nilai Tukar Rupiah Atas Dollar AS terhadap Kinerja Saham Perusahaan Property dan Real Estate di Indonesia, Jurnal Ekonomikawan, Jilid 17 No.1.

Maya Sari, Jufrizen. (2019). Pengaruh Price Earning Ratio Dan Return On Asset Terhadap Price To Book Value, Vol. 10 (2)

Purwanto Suharyadi. (2004). Statistika: Untuk Ekonomi dan Keuangan Modern. Jakarta: Salemba Empat.

Sujarweni, V. Wiratna. (2017). Analisis Laporan Keuangan : Teori, Aplikasi, \& Hasil Penelitian. Yogyakarta: Pustaka Baru Press.

Syafrida Hani. (2017). Analisis Penggunaan Asset Dalam Mengukur Profitabilitas PT. Perusahaan Gas Negara (Persero) Tbk Medan, Vol. 1 No. 1 